\author{
O.D. Bezler ${ }^{1}$, Z.N. Borbasova ${ }^{2}$, S.N. Ulakov ${ }^{3}$ \\ Karaganda Economic University of Kazpotrebsoyuz, Kazakhstan \\ 'bezleroxana@mail.ru, ${ }^{2}$ borbasova@mail.ru, ${ }^{3}$ __ulakov@mail.ru \\ ${ }^{1}$ https://orcid.org/0000-0002-6717-7471, ${ }^{2}$ https://orcid.org/0000-0002-5387-6394, \\ ${ }^{3}$ https://orcid.org/0000-0002-6867-2407 \\ ${ }^{2}$ Scopus Author ID: 57148334500, ${ }^{3}$ Scopus Author ID: 57148290800
}

\title{
The study on employers' satisfaction with economics graduates in Karaganda region
}

\begin{abstract}
Object: In modern social and economic conditions, to solve the problem of employment of graduates of higher education institutions it is necessary to develop approaches, organizational and methodical principles of creation and functioning of the system of assistance in the employment of graduates. This system of employment assistance should be integrated into the system of education of the university and should match modern social conditions. It is important to develop new mechanisms for interaction between the higher education system and the labor market.

Methods: To determine the set of competencies that a graduate should possess to be competitive in the labor market, the authors conducted a marketing study on employers' satisfaction with economics graduates and identified the competencies required by the labor market. The survey was conducted among managers of state enterprises and business organizations in Karaganda city. Intending to improve its representativity, the survey concerned the economics graduates, as the leading universities of Karaganda are generally focused on providing educational services in economic specialties.

Results: In the article, the authors show the regional specifics of the employment of graduates-economists of higher educational institutions. At the same time, the acquired competencies in the process of purchasing educational services should satisfy the needs of the labor market.

Conclusions: Based on the results of the study, the authors gave practical recommendations on the development of new organizational and economic mechanisms for integrating the labor market and educational services market.
\end{abstract}

Keywords: labor market, higher education services market, graduate's competencies, labor market need, labor market demand, higher education services market supply, employment.

\section{Introduction}

When training future specialists, the entities of the educational services market should take into account the prospects for their further employment based on the real needs of the national economy. Besides, a future graduate of a higher education institution should also be aware of employment opportunities after receiving an educational service. The share of graduates of higher education institutions employed and working in their specialty within the first year after graduation is an indicator of the national ranking of higher education institutions. Therefore, the increase of employment guarantee after graduation is an important competitive advantage of the higher education institution on the market of educational services, which attracts more applicants. The labor market and educational services market are the subject of serious scientific research in the modern economy; the search for ways to ensure their mutually beneficial functioning has been unsuccessful so far. In international practice, a sufficient number of modern scientific works are devoted to the interaction of the educational services market and the labor market, but the lack of effective modern interaction is recognized by all authors without exception.

\section{Literature Review}

The labor market and the educational services market are the subject of serious scientific research in the modern economy. The search for ways to ensure their mutually profitable functioning has collapsed. In international practice, a sufficient number of modern scientific works is devoted to interaction of the educational services market and the labor market. All authors without any exception recognize the absence of an effective modern interaction.

Study interaction of the labor market and the higher education market using automated data collecting systems related to the labor market and its saturation with certain specialists at the regional level determining a regional feature of the investigated markets interaction (Avdeyenko, Bakayev, 2014).

Ye.Yu. Kostina, N.A. Orlova do research based on an expert opinion analysis, career expectations and college students' intentions according to which the authors link further development prospects of labor mar- 
kets and educational services with the fact that employers and other consumers of college services will participate in development of requirements for a future graduate that, in general, will have a qualitative impact on both markets (Kostina, Orlova, 2016).

Ye. Gushchina considers current problems of the higher education system highlighting the problems in absence of connection between the labor market and the educational services market, in decrease of intellectual potential of young people and commercialization of higher education (Gushchina, 2017).

The work of M.V. Borisenko is of particular interest where he holds the view and we support concerning this view, that, unfortunately, most often when providing a student with a full educational services package the educational services market completes his mission. And, with the acquired competencies, such a student moves to the labor market and there occurs interaction of the educational services market product with a subject of the labor market. At the same time, the assessment of student's competencies received shall be carried out by an educational institution, which, according to the university, provided one a high level. Such a situation excludes an objective assessment of acquired competencies quality of an applicant. In the result, the labor market receives a specialist who does not meet the requirements and expectations of an employer (Borisenko, 2017).

N.A. Perevozchikova, T.D. Vasilenko define in their work the conceptual foundations of the labor market and the higher education services market at the current stage of their interaction (Perevozchikova, Vasilenko, 2018).

Given that there is considerable competition in the educational services market, so, unfortunately, it leads not to an increase in the educational service quality, but to overproduction of specialists in certain areas. The problem is that such data should be provided by macroeconomic forecasts of the country's economic development. Partly, they have to be corrected by employers' applications on short and long term period, for this purpose the company shall have a developed planning system which is not entirely possible in economic realities, which generally indicates the need in development of certain mechanisms for integrating the labor markets and educational services. Thus, increasing of an employment guarantee after obtaining an educational service is an important competitive advantage of a university in the higher education services market which problems we have considered in previous studies (Sedlarski, Bezler, 2017; Borbasova, Bezler, 2018; Borbasova, Sedlarski, Bezler, 2019).

Interaction processes have become a special form of society formation. In the scientific community, there is no clear understanding of interaction which generally complicates perception of the investigated subject. This concept interpretation is extremely broad and is considered depending on the field of its application, at the same time, having a close interdisciplinary connection (Bosovskaya, 2013).

Digital technologies are intensively fallen within the scope of human economic activity, under their influence employment is transformed, workforce mobility and innovation increase which, in general, leads to change of an employer's requirements to specialist competencies. It poses new challenges for universities to meet the urgent needs of business - specialist training whose competences are characterized by the digital literacy, the ability to learn independently, the virtual interaction, and the ability to produce innovations.

Today, the competition between universities has shifted both domestically and between states, filled with new content. Academic globalization encourages universities to become more entrepreneurial and to take an active part in the struggle for more successful students, faculty, and competition for research grants, for which they must have administrative and academic autonomy in their activities (Tapenova, Bugubayeva, Kupalova, 2020).

The works devoted to the labor content changes, its organization, and personnel skills under the influence of informatics and computer technologies are made by Handel M. J. (Handel, 2008), Green F. (Green, 2012), Seo H. J., Lee Y. S., Hur J.J., Kim J.K. belong to (Seo, Lee, Hur, Kim, 2012), Frey C. B., Osborne M. A. (Frey, Osborne, 2013), Bulasheva A.A., Kusayinov T.A. (Bulasheva, Kusayinov, 2019).

Changes occurring in the labor market are closely interrelated and determine transformation of the higher education system were studied in the works of such scientists as Youssef A. B, Dahmani M. (Youssef, Dahmani, 2008), Sampath Kumar B.T. and Manjunath G. (Sampath Kumar, Manjunath, 2013), CastilloMerino D., Serradell- Lopez E. (Castillo-Merino, Serradell-Lopez, 2014). However, relationship between the digital segments of labor markets and higher education, as well as their mutual influence, is poorly studied and requires a profound research - Spencer-Oatey H., Dauber D., Jing J. (Spencer-Oatey, Dauber, Jing, 2017). Professional competency issues are widely discussed by the international scientific community (Velasco, 2014). 
Having studied a certain vast literature in science we can conclude. The interaction is a form of subjects' association; mechanisms and methods of combination; coordinated development; deepening of interaction, cooperation, and partnership. Therefore, "interaction of the labor market and the higher education services market" is such an interaction of the organizational and economic mechanisms of the studied markets when the supply of vocational and qualification structure of personnel coincides with the demand thereof, despite the multifactorial impact.

\section{Method}

To determine the set of competencies that a graduate should possess to be competitive in the labor market, the authors conducted a marketing study on employers' satisfaction with economics graduates and identified competencies required by the labor market. The survey was conducted among managers of state enterprises and business organizations in Karaganda city. Intending to improve its representativity, the survey concerned the economics graduates, as the leading universities of Karaganda are generally focused on providing educational services in economic specialties. At the time of the study, 7 higher education institutions of Karaganda city and Karaganda region train specialists in the economic and business fields, including Karaganda State University named after Academician Ye.A. Buketov, Karaganda State Technical University, Karaganda State Industrial University (in Temirtau town), Karaganda Economic University of Kazpotrebsoyuz, Bolashak Academy, Central Kazakhstan Academy, Zhezkazgan University named after A.O. Baykonurov.

The survey was conducted using a pre-designed questionnaire. To calculate the number of respondents of the representative sample, the authors used an online calculator, which showed that the sample volume of the whole population of 23.7 thousand enterprises (the average number of enterprises in Karaganda region for 2013-2017) should include 96 enterprises (online sample calculator http://socioline.ru/rv.php). The whole population is 23,700 enterprises. Confidence probability (confidence, reliability) is $95 \%$. Confidence interval of error $- \pm 10 \%$. Thus, the management of 96 enterprises (among them: directors, heads of departments, heads of state institutions, law enforcement agencies, banking and financial organizations, private enterprises, service sectors, as well as individual entrepreneurs, managers, leading experts, etc.), where graduates work, took part in the survey. The number of employees in these organizations varies from 3 to 1200 people.

\section{Results}

The results of the employers' survey showed the following.

The need of the labor market for economics specialists is a certain element of its integration mechanism with the educational services market. Based on the expert evaluation, the need of the labor market is distributed as follows: $25 \%$ of employers ticked the response "finance", $19 \%$ of employers ticked the response "economy", 15\% of employers ticked the response "accounting and audit" (Figure 1). The need for financial experts on the labor market is superior due to the high density of financial enterprises in the region under study.

The involvement of graduates of higher education institutions of the region in the activity of the state enterprises and small and medium-sized businesses is an important indicator. In the next question, respondents were asked to indicate whether economics graduates who had graduated in recent years worked in their enterprise (Figure 2). Employers who indicated the largest number of graduates working in their enterprises $(61 \%)$ mentioned that the graduates mainly worked in the following departments: financial and economic departments, legal departments, departments of small and medium-sized businesses, departments of organizational and personnel service, information department, etc.

Such an indicator as "time spent on finding a job" is a rating and significant indicator of interaction between the market of educational services and the labor market. The authors were interested in the answer to the following question: "How many graduates (those who graduated within the last 1-2 years) do you employ per year? Based on the analysis of the experts' answers, Figure 3 shows that per year the largest number of enterprises employ only 1-2 graduates per without work experience.

However, the number of employed graduates depends not only on work experience but also on the number of employees in the organization. 


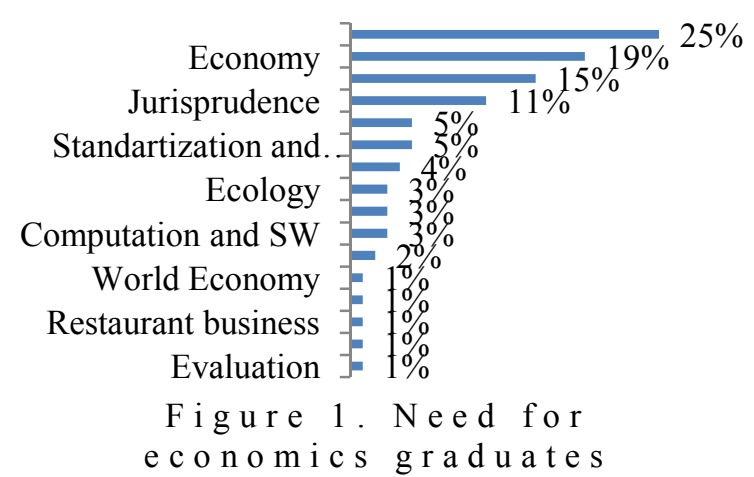

More than 10 graduates $12 \%$

Figure 3. Need for graduates without work experience

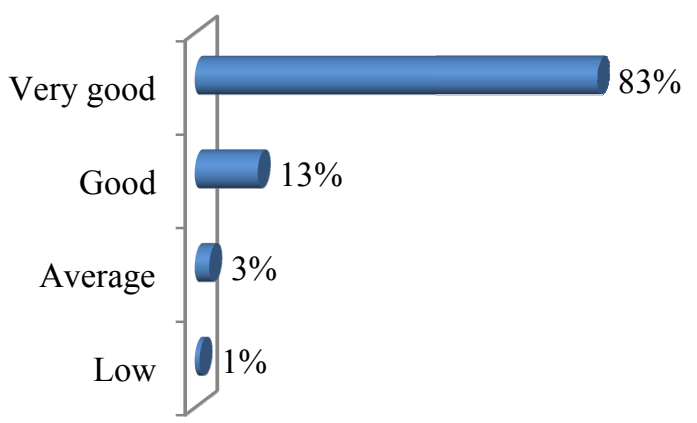

Figure 5. Dynamics in training level of economics graduates

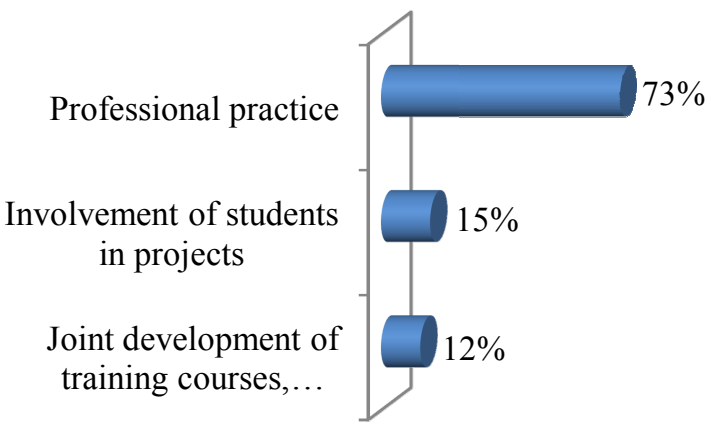

Figure 7. Organizational mechanisms for integrating the labor market and educational services market

Note-prepared by authors based on the study

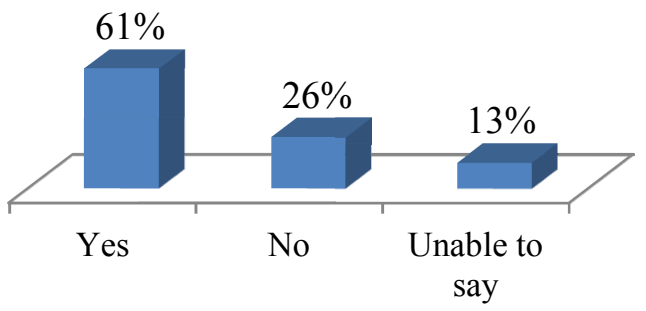

Figure 2. De mand in economics graduates

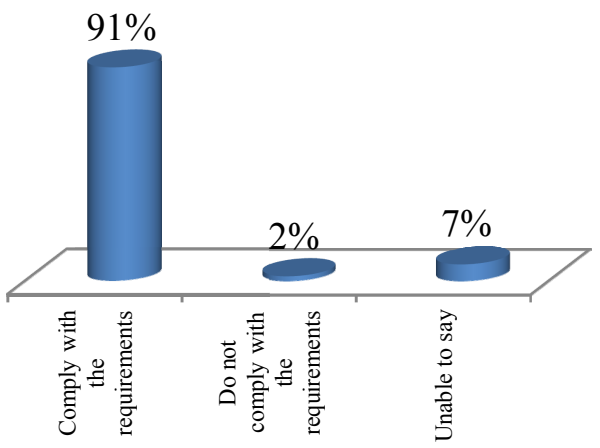

Figure 4. Compliance of graduates' competencies with the employers' requirements

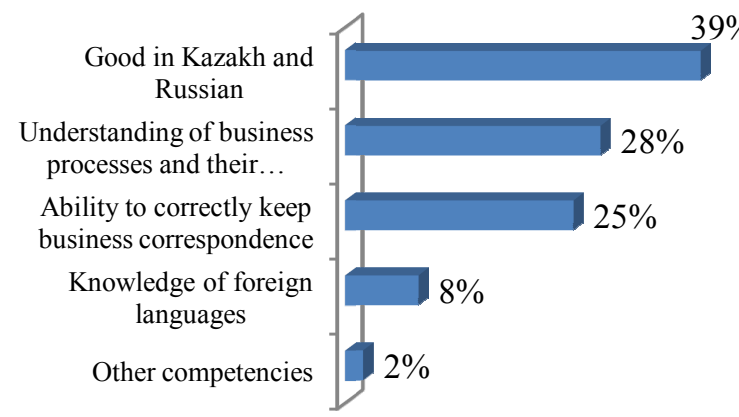

Figure 6. General professional competencies of a graduate

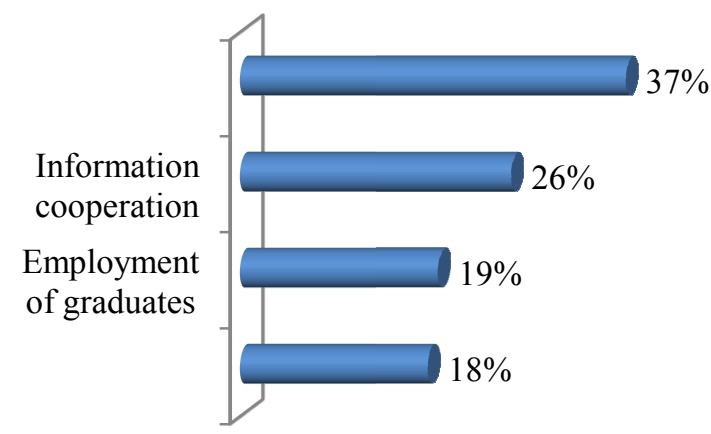

Figure 8. Readiness for social partnership with higher education institutions 
$86 \%$ of surveyed employers are satisfied with the level of training of economics graduates (for example, professional training, ability to build relationships in a team, analytical skills, independence, initiative, etc.). Employers pointed out the following strong aspects of graduates' training:

- good adaptability to new conditions;

- initiative;

- good professional training;

- the organization, communication skills;

- independence;

- ability to build relationships in a team.

$14 \%$ of employers consider that they are not satisfied with the level of training of graduates, as the graduates lack practical knowledge.

The level of professional competencies that a graduate received during his/her studies at the higher education institution and self-education is the most important indicator of his/her competitiveness in the labor market. The employers answered positively to the question: "In your opinion, does the level of graduates' knowledge meet the needs of your company (organization)?" (Figure 4). The absolute majority (91\%) of employers answered that the level of knowledge of graduates fully meets the needs of their organization or company. Only $2 \%$ of respondents consider that the level of knowledge of graduates does not meet the needs of their organization, and 7\% of respondents were unable to answer. These answers allow concluding that employers are generally satisfied with the level of training of economics graduates in Karaganda region.

As for the analysis of changes in the dynamics of the qualitative level of graduates' training, according to the answers, most employers note a noticeable increase in the level of graduates' training, especially in specialties: "finance", "economy" and "state and local government". Thus, $83 \%$ of employers note that the level of graduates' training is "very good", 13\% - "good", 3\% - "average" and 1\% - "low". Employers also note that every year the level of graduates' training increases and meets the standards and requirements of their organization (Figure 5).

According to the respondents' answers, the most widely used system for selection of candidates for a job is as follows: sending a CV - an interview (or testing) - internship - probation period - recruitment. In most cases, during the selection of candidates for a job, not only knowledge of specialty but also the personal qualities and skills of graduates are taken into account (Figure 6).

According to respondents, the main general professional skills that a graduate should possess are "good knowledge of Kazakh, Russian languages", "understanding of business processes and their interrelations in the organization" and "ability to correctly conduct business negotiations and keep business correspondence". When choosing the "other" option, employers note professional competence, ability to improvise, desire to work and study, knowledge of professional disciplines, knowledge of English, analytical skills, and stress resistance. Employers also note that in many cases, good knowledge of languages enhances prospects for career and personal growth.

Employers were asked to give the main reasons for employment and employment rejection. Reasons for employment and employment rejection are presented in Table 1.

Table 1.Employer's main criteria for employment graduates of higher education institutions

\begin{tabular}{|l|l|}
\hline \multicolumn{1}{|c|}{ Reasons for employment } & \multicolumn{1}{c|}{ Reasons for employment rejection } \\
\hline $\begin{array}{l}\text { focus on professional and career development; } \\
\text { stable company in the labor market; } \\
\text { compliance with qualification requirements; } \\
\text { stable salary; } \\
\begin{array}{l}\text { interesting work; } \\
\text { the successful professional practice of a graduate. }\end{array}\end{array}$ & $\begin{array}{l}\text { noncompliance with qualification requirements; } \\
\text { failure to pass exams, tests prescribed by law; } \\
\text { lack of work experience; } \\
\text { lack of vacancies; } \\
\text { lack of a diploma; } \\
\text { slow learning; } \\
\text { insufficient level of professional competencies. }\end{array}$ \\
\hline Note-prepared by authors based on the study & \\
\hline
\end{tabular}

Readiness and mechanisms for integrating the labor market with the educational services market are quite primitive at the moment (Figure 7). The chart shows that the main form of cooperation between organizations and higher education institutions is "professional practice" (73\%), while other mechanisms of cooperation between higher education institutions and enterprises are underdeveloped.

Afterward, employers were asked the following question: "Are you interested in developing educational programs and in planning vocational training for young people in professions which are important for your 
enterprise (institution), if yes, in what form?". $87 \%$ of respondents answered positively, and $13 \%$ of respondents answered "no", noting the lack of free time for developing educational programs and lack of interest in the development.

To the question "Are you interested in accepting students for professional and pre-graduation practice in the specialties of your enterprise, institution? Specify the conditions under which (without paying a salary to students, with partial or full payment, for how long)" respondents unanimously answered positively. They note that they are ready to accept graduates for training (professional practice and pre-graduation practice) without pay. Employers noted that the period of practice should last from 20 days to 6 months.

The social partnership between labor market enterprises and higher education institutions is a very efficient organizational and economic mechanism for integrating the labor market with the educational services market. Respondents gave quite different answers to the question: "In what form of the social partnership are you ready to cooperate with higher education institutions?". It generally indicates that respondents are already working in this direction or have thought about it (Figure 8). The distribution of respondents' answers shows that the main form of social partnership with higher education institutions remains "provision of jobs for professional and pre-graduation practices" and "information cooperation", which involves placing information on their resources (in the organization and at the university), banner exchange, etc.

In conclusion, employers were asked to give in a free form any additional wishes and remarks regarding the quality of personnel training at higher education institutions. The majority of respondents (98\%) answered that they did not have any remarks and wished success in personnel training, further development, and prosperity of higher education institutions. $2 \%$ of employers noted that graduates lacked practical experience.

\section{Discussion}

As the analysis of respondents' answers showed, in the region, there is a need for specialists in economics who are trained at the universities of the region. All respondents are unanimously satisfied with the level of training of university graduates. This is confirmed by their positive answers. This fact indicates that university graduates are in demand in the labor market and show the necessary knowledge.

According to respondents, graduates are selected for employment mostly through interviews or testing. Competitive interviewing remains one of the most important elements in the selection process. When employing a graduate, the employer wants to know as much information about the applicant as possible and the more detailed information its, the easier and faster this graduate can be employed. Different employers are interested in different professional competencies. Such requirements of employers result in a large number of different parameters necessary for the description of applicants and their requirements.

Representatives of the enterprises and organizations of different branches - state organizations, manufacture, services sectors, wholesale and retail trade, tourism, agriculture took part in the study, but despite the difference of types of the enterprises, their spheres of activity and corporate cultures, the requirements to employees are surprisingly similar.

According to the respondents, the fundamental competencies that a graduate should have are:

- general professional competencies: understanding of business processes of enterprises and their interrelations; ability to correctly keep business correspondence, prepare reports, presentations, and other documents;

- communication competencies: the ability to present a produced product or service; the ability to express the ideas clearly; the ability to conduct negotiations;

- analytical competencies: systematic thinking, analytical thinking, ability to learn quickly;

- innovative competencies: the vision of new opportunities; ability to generate new ideas, initiative, independence;

- behavioral characteristics: responsibility, discipline; ability to use time effectively, ability to work in a team and achieve collective goals.

As determining reasons for rejecting the employment of graduates, the respondents also mentioned high salary expectations and the lack of professional experience. Respondents noted that the following forms of university interaction with organizations, institutions, enterprises were the most preferable: organization and implementation of all types of practices; they showed little willingness to participate in the joint development of educational programs and low interest of employees of the organization in the educational process (as teachers). 


\section{Conclusions}

Thus, based on the results of the study, it is possible to give the following recommendations:

- for analyzing the labor market for its development trends, it is necessary to track changes in employers' requirements to candidates. This will make it possible to identify permanent requirements that change over time and orient training towards meeting these requirements, first and foremost;

- to design educational programs taking into account practice-oriented parameters;

- to improve the organization of students' professional practice following the new recommendations of the Ministry of Education and Science of the Republic of Kazakhstan;

- to carry out a systematic analysis of the results of all types of professional practice, to improve its effectiveness;

- to strengthen links with the business community, to develop social partnership;

- to increase the interest of employers in creating various mechanisms of cooperation between the higher education institution and enterprises. As foreign practice shows, one of the effective tools is tax benefits or financial assistance to employers who employ graduates. Such a measure is widely used in France, Poland, the Czech Republic, and Singapore;

- to step-by-step create new organizational structures aimed at developing general and professional competencies of graduates.

\section{References}

Avdeenko, T., Bakaev. M. (2014). Modeling information space for decision-making in the interaction of higher education system with regional labor market. 12th International Conference on Actual Problems of Electronic Instrument Engineering (APEIE), 617-623. Doi:10.1109/APEIE.2014.7040759.

Borbasova, Z.N., Bezler, O. (2018). Econometric assessment of factors of graduate employability. Journal of Applied Economic Sciences, 6(60), 1734-1739.

Borbasova, Z.N., Sedlarski,T. \& Bezler, O. (2019). Analysis of the modern interaction of the labor market and the professional education in Kazakhstan. Bulletin of the Karaganda University, 1(93), 98-105.

Borisenko, M.V. (2017). Rynok rabochej sily kak rezultat vzaimodejstviya rynka obrazovatel'nyh uslug i rynka truda [The labor market as a result of the interaction of the educational services market and the labor market]. Vestnik instituta ekonomicheskih issledovanij [Vestnik of the Institute of Economic Research], 4(8), 34-44 [In Russian].

Bosovskaia, M.V. (2013) Teoreticheskie osnovy integracii: multidisciplinarnyj podhod [Theoretical foundations of interaction: a multidisciplinary approach]. Sbornik nauchnyh trudov "Problemy sovremennoj nauki» [Collection of scientific papers «Problems of Modern Science»]. Vypusk 7 (chast 3) [Issue 7 (part 3)], 125-132 [In Russian].

Bulasheva, A.A., Kusayinov,T.A. (2019) Impact assessment of investments in education on the development of human capital and its influence on the economic growth. Bulletin of the Karaganda University, 1(93), 41-48.

Castillo-Merino, D., Serradell-Lopez, E. (2014). An analysis of the determinants of students' performance in e-learning. Computers in Human Behavior, 30, 476-484. Doi:10.1016/j.chb.2013.06.020.

Frey, C. B., Osborne, M. A. (2013) The future of employment: how susceptible are jobs to computerization? Oxford Martin School: Oxford. Retrieved from https://www.oxfordmartin.ox.ac.uk/downloads/academic/The Future of Employment.pdf/.

Green, F. (2012). Employee involvement, technology and evolution in job skills: a task based analysis. Industrial Labor Relations Review, 65 (1), 36-67. Doi:10.1177/001979391206500103.

Gushina, E. (2017). Factors, criteria and determinants of the increase in the effectiveness of university education in Russia. The International Journal of educational management, 31(4), 485-496. doi:10.1108/IJEM-02-2016-0038.

Handel, M. J. (2008). Measuring job content: skills, technology, and management practices. University of WisconsinMadison, Institute for Research on Poverty. Retrieved from https://www.irp.wisc.edu/publications/dps/pdfs/dp135708.pdf.

Kostina, E.Yu., Orlova, N.A. (2016). Choice of employment career by Russian students in modern labor market conditins. Indian Journal of Science and Technology, 9(44). Doi:10.17485/ijst/2016/v9i44/104710.

Orynbassarova, Y., Serikova, G., Pritvorova, T., Legostayeva, A., Kuttybaeva, N. \& Komekbayeva, L. (2019). Parttime and temporary employment in modern conditions of the Republic of Kazakhstan: scope and priorities of social protection, Entrepreneurship and Sustainability Issues 7(1): 731-746. Doi:10.9770/jesi.2019.7.1(52).

Perevozchikova, N.A., Vasilenko, T.D. (2018). Konceptualnaya osnova mekhanizma vzaimodejstviya rynka truda i rynka obrazovatelnyh uslug [The conceptual basic of the mechanism of cooperation between the labor market and market of educational services]. Vestnik Instituta ekonomicheskih issledovanij [Vestnik of the Institute of Economic Research],1(9), 14-21 [In Russian].

Sampath Kumar, B. T., Manjunath, G. (2013). Internet use and its impact on the academic performance of university teachers and researchers: a comparative study. Higher Education, Skills and Work-based Learning, 3 (3), 219-238. Doi:10.1108/HESWBL-09-2011-0042. 
Sedlarski, T., Bezler, O. (2017). Assessment of internal opportunities of resource providing of a higher education institution. Materials of the international scientific-practical conference «Modern Economics and Education: Problems, Opportunities and Development Prospects». Almaty «Almaty Academia of Economics and Statistics», March 29, 402-407.

Seo, H. J., Lee, Y. S., Hur, J.J. \& Kim, J.K. (2012). The impact of information and communication technology on skilled labor and organization types. Information systems frontiers, 14 (2), 445-455.

Spencer-Oatey, H., Dauber, D., Jing, J. (2017). Chinese students' social interaction into the university community: hearing the students' voices. The International Journal of Higher Education Research, 74, 739-756. Doi:10.1007/s10734-016-0074

Tapenova, G. S., Bugubayeva, R. O. \& Kupalova G. (2020). State administration of higher education in the Republic of Kazakhstan: problem and perspectives. Bulletin of the Karaganda University, 1(97), 141-153. Doi:10.31489/2020Ec1/141-153

Velasco, M.S. (2014). Do higher education institutions make a difference in competence development? A model of competence production at university. The International Journal of Higher Education Research, 68(4), 503-523. Doi:10.1007/s10734-014-9725-1.Youssef, A.B., Dahmani, M. (2008). The impact of ICT on student performance in higher education: direct effects, indirect effects and organizational change. RUSC: Universities and Knowledge Society Journal, 5 (1), 45-56.

\title{
О.Д. Безлер, З.Н. Борбасова, С.Н. Улаков
}

\section{Қарағанды аймағындағы экономикалық мамандықтар түлектеріне жұмыс берушілердің қанағаттануын зерттеу}

\begin{abstract}
Аңдатпа
Maқ̧cambl: Қазіргі әлеуметтік-экономикалық жағдайларда университет түлектерін жұмысқа орналастыру міндеттерін шешу жоғары оқу орнының білім беру жүйесіне интеграцияланған, қоғамның қазіргі заманғы жағдайларына сай келетін түлектерді жұмысқа орналастыруға жәрдемдесу жүйесін құру және жұмыс істеу тәсілдерін, ұйымдастырушылық және әдістемелік қағидаларын әзірлеуді талап етеді. Жоғары білім беру жүйесі мен еңбек нарығы өзара іс-қимылының жаңа тетіктерін әзірлеу қажет.

Әдісі: Еңбек нарығында бәсекеге қабілеттілікті қамтамасыз ету үшін бітіруші ие болуы тиіс құзыреттіліктерді анықтау мақсатында мақалада авторлар жұмыс берушілердің экономикалық мамандықтар түлектерінің қанағаттануына маркетингтік зерттеу және еңбек нарығына қажетті құзыреттіліктерге анықтау жүргізген. Сауалнама Қарағанды қаласында мемлекеттік кәсіпорындар мен бизнес құрылымдардың басшылары арасында өткізілген. Репрезентативтілік мақсатында сауалнама экономикалық мамандықтардың түлектеріне қатысты болды, себебі жетекші жоғары оқу орнындарында білім беру қызметінің жалпы бағыты - бұл экономикалық бейіндегі мамандықтар.

Қорытынды: Мақалада авторлар жоғары оқу орындарының экономист-түлектерін жұмысқа орналастырудың аймақтық ерекшеліктерін көрсеткен. Сонымен бірге, білім беру қызметтерін сатып алу процесінде алынған құзыреттер еңбек нарығының қажеттіліктерін қанағаттандыруы керек.

Тұжырымдама: Зерттеу нәтижелері бойынша еңбек нарығы мен білім беру қызметтері нарығын интеграциялаудың жаңа ұйымдық-экономикалық тетіктерін әзірлеу бойынша тәжірибелік ұсыныстар берілген.

Кілm сөздер: еңбек нарығы, жоғары білім беру қызметтері нарығы, түлектің құзыреті, еңбек нарығының қажеттілігі, еңбек нарығының сұранысы, жоғары білім беру қызметтері нарығының ұсынысы, түлектерді жұмысқа орналастыру.
\end{abstract}

\section{О.Д. Безлер, З.Н. Борбасова, С.Н. Улаков}

\section{Исследование удовлетворенности работодателей Карагандинского региона выпускниками экономических специальностей}

\section{Аннотация}

Цель: В современных социально-экономических условиях решение задачи трудоустройства выпускников университета требует выработки подходов, организационных и методических принципов создания и функционирования системы содействия трудоустройству выпускников, интегрированной в систему образования вуза, адекватной современным условиям общества. Необходима разработка новых механизмов взаимодействия системы высшего образования и рынка труда.

Memoдb: С целью определения набора компетенций, которыми должен обладать выпускник для обеспечения конкурентоспособности на рынке труда, в статье авторами было проведено маркетинговое исследование удовлетворенности работодателей выпускниками экономических специальностей и выявление компетенций, необходимых рынку труда. Опрос был проведен среди руководителей государственных предприятий и бизнесструктур в г. Караганде. В целях репрезентативности опрос касался выпускников экономических специально- 
стей, поскольку в ведущих вузах г. Караганды общая направленность образовательных услуг - это специальности экономического профиля.

Pезультаты: В статье авторами показана региональная специфика трудоустройства выпускниковэкономистов высших учебных заведений. При этом получаемые компетенции в процессе покупки образовательной услуги должны удовлетворять потребности рынка труда.

Bblвoдbl: По результатам исследования даны практические рекомендации по разработке новых организационно-экономических механизмов интеграции рынка труда и рынка образовательных услуг.

Ключевые слова: рынок труда, рынок услуг высшего образования, компетенции выпускника, потребность рынка труда, спрос рынка труда, предложение рынка услуг высшего образования, трудоустройство.

\section{References}

Avdeenko, T., Bakaev, M. Modeling information space for decision-making in the interaction of higher education system with regional labor market / T. Avdeenko, M. Bakaev // 12th International Conference on Actual Problems of Electronic Instrument Engineering (APEIE). — 2014. — P. 617-623. — (doi:10.1109/APEIE.2014.7040759).

Borbasova, Z.N., Bezler, O.D. Econometric assessment of factors of graduate employability [Text] / Z.N. Borbasova, O.D. Bezler // Journal of Applied Economic Sciences. — 2018. — № 6(60). — P. 1734-1739.

Borbasova, Z.N., Sedlarski, T., Bezler, O.D. (2019). Analysis of the modern interaction of the labor market and the professional education in Kazakhstan [Text] / Z.N. Borbasova, T. Sedlarski, O.D. Bezler // Вестн. Караганд. ун-та. Сер. Экономика. — 2019. — № 1(93). - C. 98-105.

Bulasheva, A.A., Kusayinov, T.A. Impact assessment of investments in education on the development of human capital and its influence on the economic growth [Text] / A.A. Bulasheva, T.A. Kusayinov // Bulletin of the Karaganda university. — 2019. - № 1(93). — C. 41-48.

Castillo-Merino, D., Serradell-Lopez, E. An analysis of the determinants of students' performance in e-learning [Text] / D. Castillo-Merino, E. Serradell-Lopez // Computers in Human Behavior. — 2014. — № 30. — P. $476-484$. doi:10.1016/j.chb.2013.06.020.

Frey, C. B., Osborne, M. A. The future of employment: how susceptible are jobs to computerization? Oxford Martin School: Oxford — 2013[online]. — (https://www.oxfordmartin.ox.ac.uk/downloads/academic/The Future of Employment.pdf/).

Green, F. Employee involvement, technology and evolution in job skills: a task based analysis [Text] / F. Green // Industrial Labor Relations Review. — 2012. — № 65 (1). — P. 36-67. — (doi:10.1177/001979391206500103).

Gushina, E. Factors, criteria and determinants of the increase in the effectiveness of university education in Russia [Text] / E. Gushina // The International Journal of educational management. — 2017. — № 31(4). — P. $485-496$. - (doi:10.1108/IJEM-02-2016-0038).

Handel, M. J. Measuring job content: skills, technology, and management practices. University of Wisconsin-Madison,

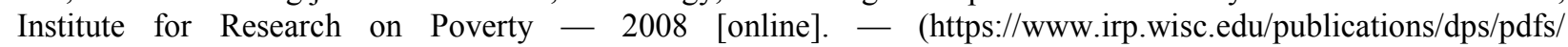
dp135708.pdf/).

Kostina, E.Yu., Orlova, N.A. Choice of employment career by Russian students in modern labor market conditins [Text] / E.Yu. Kostina, N.A. Orlova // Indian Journal of Science and Technology. — 2016. — № 9(44). — (doi:10.17485/ijst/2016/v9i44/104710).

Orynbassarova, Y., Serikova, G., Pritvorova, T., Legostayeva, A., Kuttybaeva, N. \& Komekbayeva, L. Part-time and temporary employment in modern conditions of the Republic of Kazakhstan: scope and priorities of social protection [Text] / Y. Orynbassarova, G. Serikova, T. Pritvorova, A. Legostayeva, N.Kuttybaeva, L. Komekbayeva // Entrepreneurship and Sustainability Issues. — 2019. — № 7(1). — P. 731-746. — (doi: 10.9770/jesi.2019.7.1(52)).

Sampath Kumar, B. T., Manjunath, G. Internet use and its impact on the academic performance of university teachers and researchers: a comparative study [Text] / B. T. Sampath Kumar, G. Manjunath, // Higher Education, Skills and Work-based Learning. — 2013. — № 3(3). — P. 219-238.-(doi:10.1108/HESWBL-09-2011-0042).

Sedlarski, T., Bezler, O. Assessment of internal opportunities of resource providing of a higher education institution [Text] / T. Sedlarski, O. Bezler // Сб. материалов междунар. науч.-практ. конф. «Современная экономика и образование: проблемы, возможности и перспективы развития». - Алматы: Алматинская академия экономики и статистики, 2017. - С. 402-407.

Seo, H. J., Lee, Y. S., Hur, J.J., Kim, J.K. The impact of information and communication technology on skilled labor and organization types [Text] / H. J. Seo, Y. S Lee, J.J Hur, J.K. Kim // Information systems frontiers. — 2012. — № 14 (2). - P. 445-455.

Spencer-Oatey, H., Dauber, D., Jing, J. Chinese students' social interaction into the university community: hearing the students' voices [Text] / H. Spencer-Oatey, D. Dauber, J. Jing, // The International Journal of Higher Education Research. — 2017. — № 74. — P.739-756. — (doi:10.1007/s10734-016-0074).

Tapenova, G.S., Bugubayeva, R.O., Kupalova G. State administration of higher education in the Republic of Kazakhstan: problem and perspectives [Text] / G.S. Tapenova, R.O Bugubayeva, G. Kupalova // Bulletin of the Karaganda University. — 2020. — № 1(97). - P. 141-153. - (10.31489/2020Ec1/141-153).Velasco, M.S. Do higher education institutions make a difference in competence development? A model of competence production at university 
[Text] / M.S. Velasco // The International Journal of Higher Education Research. — 2014. — № 68(4). — P. 503523. - (doi:10.1007/s10734-014-9725-1).

Youssef, A.B., Dahmani, M. The impact of ICT on student performance in higher education: direct effects, indirect effects and organizational change [Text] / A.B. Youssef, M. Dahmani // RUSC: Universities and Knowledge Society Journal. — 2008. — № 5 (1). — P. 45-56.

Борисенко М.В. Рынок рабочей силы как результат взаимодействия рынка образовательных услуг и рынка труда [Текст] / М.В. Борисенко // Вестн. Ин-та экон. исслед. — 2017. — № 4(8). — С. 34-44.

Босовская М.В. Теоретические основы интеграции: мультидисциплинарный подход [Текст] / М.В. Босовская // Сб. науч. тр. «Проблемы современной науки». - Ставрополь: Центр науч. знания «Логос», 2013. — Вып. 7 (Ч. 3). - C. $125-132$.

Перевозчикова Н.А. Концептуальная основа механизма взаимодействия рынка труда и рынка образовательных услуг [Текст] / Н.А. Перевозчикова, Т.Д. Василенко // Вестн. Ин-та экон. исслед. — 2018. - № 1 (9). C. 14-21. 